\title{
NEKE METODOLOŠKE PRETPOSTAVKE ZA PISANJE NAUČNOG ILI STRUČNOG ČLANKA
}

\section{SAŽETAK}

U ovome radu se skreće pažnja na neke temeljne metodološke pretpostavke u pisanju naučnog ili stručnog rada koje mogu biti od koristi svima onima koji se bave istraživanjem i koji žele publicirati rezultate svoga istraživanja. Autor posebno apostrofira na značaj samog predmeta istraživanja, relevantnost istraživanog pitanja, uvažavanje standarda naučnih dokaza, te argumentaciju $i$ razumljivost naučnog rada. Svaki naučni članak svojim sadržajem treba utjecati na razrješavanje istraživanog problema, odnosno ako se radi o stručnome članku da svojim pristupom da novu dimenziju primjene ili objašnjenja pitanja koje je u fokusu elaboracije. Također, i jedan $i$ drugi tip članka mora odašiljati ideje i mišljenja koja će biti od koristi za čitaoce. Pisanje naučnih $i$ stručnih radova podrazumijeva poznavanje same materije o kojoj se piše, korištenje odgovarajućih metoda, uvažavanje metodoloških standarda $i$ poštivanje jezičkih i stilskih normativa.

Ključne riječi: Kompozicija naučnog rada, metodologija, naučni članak, naučni jezik, naučnoistraživački rad, stil pisanja, stručni članak.

\section{Uvod}

Naučni članak, u pravilu, predstavlja originalni rezultat istraživanja u publikacijama koje su lahko dostupne međunarodnoj naučnoj javnosti, a napisan je na način da se istraživanje, koristeći iste metode, može provjeriti i doći do isti naučnih rezultata. S druge strane, stručni članak ne predstavlja rad koji sadrži originalne rezultate istraživanja, već se u njemu iznose poznate spoznaje, odnosno rezultati istraživanja do kojih se ranije došlo. Dakle, za razliku od naučnog članka, sadržaj stručnog članka nije iznošenje novih spoznaja, već se prezentiraju informacije o već poznatim

\footnotetext{
${ }^{1}$ Pravni fakultet u Bihaću
} 
spoznajama s drukčijim pristupom, nego što je to ranije učinjeno i u cilju njihove primjene u praksi.

Komponiranje naučnog ili stručnog rada predstavlja ozbiljan posao pri kojem treba uvažavati savremene metodološke zahtjeve i standarde. Što su temeljne pretpostavke koje svaki autor naučnog ili stručnog članka treba da zadovolji prije slanja rukopisa i njegovog publiciranja? Cjelovit odgovor na ovo pitanje nije moguće dati, ali ćemo u ovome radu pokušati ponuditi neke od temeljnih pretpostavki koje treba zadovoljiti prilikom pisanja naučnih ili stručnih radova prije njihovog publiciranja. Predstaviti ćemo neke od najčešćih pogrešaka s kojima se susreću mnogi autori u pisanju svojih radova, a nerijetko njihove rukopise vraćaju urednici i recenzenti na doradu, odnosno prilagodbu općevažećim naučnim standardima. Ovdje ćemo razmatrati neke od tih standarda na temelju kojih se vrši selekcija rukopisa, kao prihvatljivih ili ne, prije njihovog objavljivanja.

\section{Kako sadržajno treba da izgleda naučni ili stručni članak}

Urednici i recenzenti kod vrednovanja rukopisa naučnih i stručnih članaka, obraćaju pažnju na četiri osnovna kriterija: predmet istraživanja, relevantnost istraživanog predmeta, uvažavanje standarda naučnih dokaza, te argumentaciju i razumljivost.

Većina časopisa, koji su upućeni naučnoj javnosti, imaju izrazito širok vidokrug naučnih oblasti koje pokrivaju, bilo da se radi o političkim analizama, tehnološkom razvoju, povijesnim rekonstrukcija, kulturološkim ili socijalnim deskripcijama i slično. Najčešće pitanje recenzenata prilikom pregledanja rukopisa $u$ uredništvu časopisa, odnosno prilikom njegovog recenziranja je: Što to iz dotičnog članka možemo naučiti?, ili Da li članak svojim sadržajem razrješava ili barem utječe na razrješavanje istraživanog pitanja? Svaki članak koji se krije iza trivijalnih ili formalnometodoloških postavki, nema veliku šansu da popuni časopisne stranice, pa čak i ako je istinit. S druge strane, članci trebaju sadržavati argumente i dokaze za postavljenu tezu koja je predmet naučne elaboracije, a što u biti omogućava akumuliranje znanja. Argumenti, izraženi u formi činjenica, njihov obim i uvjeti u kojima egzistiraju, trebaju biti jasno iskazani, tako da ne postoji konfuzija oko onog što jeste i što nije dokazano. Izjave o činjenicama trebaju biti 
pravilno dokumentirane. Dokazi trebaju biti u potpunosti objašnjeni, tako da ih čitalac može provjeriti, koristeći odgovarajući postupak.

Zbog kompleksnosti pitanja koja su predmet istraživanja, kod pisanja naučnog ili stručnog članka, potrebno se je suočiti $\mathrm{s}$ legitimnim, često i brojnim protuargumentima. Autor u tome slučaju treba rezimirati raspravu, kao sastavni dio članka, te sučeljavajući argumente $\mathrm{u}$ formi dokaza izvesti naučni zaključak.

Komponiranje naučnog ili stručnog rada podrazumijeva poštivanje općeprihvaćenih načela, a ovdje apostrofiramo na njih pet:

1. Načelo jedinstva kompozicije. Postiže se ako se tokom pisanja naučnog ili stručnog rada ostvari jedinstvo cilja, misli i izlaganja. Drugim riječima, autor treba znati što konkretnom temom želi postići, da se svi dijelovi rada mogu misaono i logički povezati, te da izbjegava nefunkcionalne digresije;

2. Načelo odabira. Pretpostavlja da se autor mora postaviti u ulogu čitaoca i iz njegove pozicije ocjeni što ga zanima, a što ne. Od posebnog je značaja da autor vrši selekciju važnog od nevažnog, odnosno da su svi dijelovi rada vezani za konkretnu temu. Najčešće pogreške kod pisanja naučnih ili stručnih radova, jesu da autori nerijetko podlegnu iskušenju suvišnih digresija. To ne znači da digresije treba potpuno isključiti, jer one ponekad mogu imati funkcionalnu ulogu u ilustriranju određenih stavova;

3. Načelo harmonije. Opći je standard koji podrazumijeva da svi dijelovi rada čine jednu logičku cjelinu i da su međusobno povezani na način da čine skladnu kompoziciju;

4. Načelo proporcije. Podrazumijeva da autor unaprijed, planski izvrši razgraničavanje ideja prema stepenu njihove važnosti, na način da glavne ideje dobiju centralno mjesto u odnosu na ostale, ili manje značajne. Ova vrsta razgraničavanja i planiranja primjenjuje se na svim razinama kompozicije (na razini cjelokupnog rada, njegovih sastavnih dijelova, paragrafa i rečenica);

5. Načelo raznovrsnosti. Podrazumijeva da naučni ili stručni rad bude raskošan u jezičkome izražavanju i prihvatljivoga stila pisanja (kako bi se izbjegla monotonija čitanja od strane 
čitaoca). Raznovrsnost se može osigurati na različite načine npr., izbjegavanjem fraza, promjenom stila, upotrebom sinonima i sl.

\section{Suprotstavljanje argumenata}

Naučni ili stručni članak koji je dobro napisan, koji je utemeljen na savremenim metodološkim standardima za recenzente, odnosno urednike časopisa, čini poprilično lahak posao u postupku ocjenjivanja. Međutim, brojni članci koji se šalju u uredništva nisu bazirani na tim standardima. Članci bi trebali ispoljavati i predstavljati ideje u razvoju koje će biti logične i pregledne čitaocu, a ne samo autoru i njegovim kolegama. Što su složenije ideje to je važnije da su one čitaocu predstavljene na što prihvatljiviji i jednostavniji način. Jednostavnost se može postići na način da se složene ideje u samome predmetu istraživanja glavne tačke predstave u kratkim crtama, a nakon toga se šire elaboriraju uz navođenje uvjeta u kojima egzistiraju, kao i argumentacije koja potkrepljuje izražene stavove i sudove. Ne treba izbjegavati da se u sklopu elaboracije istraživanog pitanja napravi dijagram navedenih argumenta (ako se radi o egzaktnim naučnim područjima), odnosno da se napravi kratak sažetak iznesenih ideja. Ovakav postupak nam olakšava da otkrijemo da li su sve veze u kompozicijskome lancu poredane na logičan način, odnosno ako nisu kako ih logički povezati. Krajnji cilj je da se postigne jasna i čista logika argumentacija, a ta logika mora biti dokaz strukturalne valjanosti naučnog ili stručnog članka.

\section{Kako pisati naučni ili stručni članak}

Pisano izlaganje rezultata naučnog istraživanja je isto tako ozbiljan posao kao i samo istraživanje. Ovdje ćemo pokušati ponuditi neke od sugestija koje mogu pomoći autorima kod pisanja naučnih ili stručnih radova. Prva preporuka je da pri pisanju naučnog ili stručnog rada počnemo sa uvodom od nekoliko paragrafa koji će dati čitaocu koncept argumenata. Kratak uvod bi trebao da odgovori na sljedeća pitanja: Koje pitanje ili pitanja su u fokusu naučnog ili stručnog rada? Zašto se ta pitanja obrađuju? Kako naučna rasprava ili aktualni događaji određuju kontekst članka? Koje odgovore članak nudi? Kakvo značenje imaju dati odgovori? Na koji način zahvataju samu debatu iz kojih su proizašla ta pitanja? Kojim argumentima je članak 
podvrgnut? Koje metode su korištene u postupku istraživanja?Kako je rad kompozicijski organizovan?

Ovako napravljen uvod trebao bi pokazati strukturu dijelova rada koji slijede. Svi navedeni elementi mogu biti primjenjivi za svaki naučni članak, ali i knjigu naučnog ili stručnog karaktera.

U postupku pisanja autori često prave greške tako što sažetke, $u$ kojima su izraženi ključni argumenti, iskazuju u formi zaključka. Sažetak (rezime, summary, zasammenfassung) je dio koji bi se trebao nalaziti u svakom značajnijem naučnom radu. Terminološki, sama riječ upućuje i na zaključak o čemu se radi, o sažetome prikazu članka ili djela u kojem se iznosi pregled, vrlo kratak sadržaj onoga što je u uvodu, središnjem dijelu i zaključku naučnog ili stručnog rada. Sažetak treba da istakne ključne argumente i da objasniti moguće implikacije istraživanja za aktuelnu raspravu. Po svom obimu sažetak sadrži do 200 riječi, ako je u pitanju naučni članak, a može biti i širi (u obliku sinopsisa) ako se radi o naučnoj knjizi. Njime se konkretno daju slijedeće naznake:

a) temeljna svrha i ciljevi istraživanja,

b) primijenjena metodologija,

c) postignuti rezultati,

d) bitni zaključci.

Kod pisanja glavnog dijela naučnog ili stručnog rada nerijetko se događa da su oni duži nego što je to realna potreba u samome postupku elaboracije istraživanog pitanja. Oni sadrže paragrafe koji su tu samo zato što ih je autor istraživao, a ne zato što su oni potrebni za logičnost argumenta kojima se nešto dokazuje. Osnovna sugestija autorima kod ovoga vida pogreške je da u postupku pisanja sklone nepotreban materijal koji može izazvati zabunu ili nerazumijevanje kod čitaoca. Svako poglavlje, paragraf i rečenica imaju smisla samo ako unaprjeđuju argumente. Selektiranje relevantnog i odbacivanje irelevantnog materijala je bolan proces za mnoge autore, ali svi oni koji su uspjeli u takvom selektiranju su napravili poboljšanje u svome pisanju, što je vrijedilo truda.

Svaki odlomak naučnog ili stručnog rada bi trebao imati unutarnju logiku, ali je zajedno nužno da čine jednu logički uvezanu 
kompozicijsku cjelinu. Forma koja se najčešće koristi kod pisanja rada i koja je kod recipijenata, odnosno naučne javnosti dobro prihvaćena, jeste da se na početku prvih paragrafa iznesu dokazi, koji su potkrepljeni činjenicama i argumentima, a odmah poslije toga da se suprotstave protuargumenti, kvalifikacije i ograničenost argumenta. Nakon što se suprotstavi i sumira argumentacija, autor ukazuje na eventualne implikacije i usmjerava čitaoca u smjeru za naredni paragraf ili sekciju rada. Svaki paragraf bi trebao biti organiziran i fokusiran na temeljno pitanje koje je izneseno na početku rada. U tom slučaju čitalac može na temelju čitanja prvih rečenica svakoga paragrafa pretpostaviti sadržaj članka.

Mnogo je učinkovitije ako autor marljivo radi $u$ interesu čitalaca, nego kada zanemari tu činjenicu. Recenzenti u svome stručnome procjenjivanju rukopisa često sugeriraju autorima, da se drže određenih pravila, kao što su: bolje je objasniti više, nego manje, definirati posebne termine, dati historijsku pozadinu pitanja, pojave ili procesa kojeg elaboriramo, navoditi primjere, pošto malen broj čitalaca dijeli autorovu upoznatost sa općim činjenicama i idejama o datom pitanju. Rad ne smije biti ni opterećen pretjeranim objašnjenjima, ali se to uvijek može ispraviti tako što ih selektiramo u drugome čitanju.

\section{Jezik i stil naučnog ili stručnog članka}

Jeziku, kao osnovnom sredstvu sporazumijevanja, i govoru koji je forma njegove primjene, svojstvene su određene norme. Tu prije svega mislimo na gramatičke i leksičke norme koje su za jezik bitne. Normama se propisuje sve ono što je u gramatičkom ili leksičkom ustrojstvu jezika dopušteno i upozorava na ono što nije prihvatljivo. Bez namjere da se zadržavamo oko pitanja konvencionalnih gramatičkih i leksičkih ustrojstava, mi ćemo ovdje naglasak dati na neke bitne elemente koji se tiču naučnog jezika i stila pisanja.

Prije svega, naglasak dajemo na česte pogreške autora kod upotrebe određenih riječi. Termini poput: slabo, jako, često, mnogo, kolosalno i slično, nerijetko se zloupotrebljava njihovo značenje, te ih autori u svojim naučnim radovima trebaju izbjegavati i koristiti termine koji će preciznije označiti ono što žele. 
Druga sugestija je izbjegavanje upotrebe prvog lica jednine (a koliko je to moguće i prvog lica množine), jer izaziva osjećaj samohvalisanja i iritiranja kod čitaoca. Umjesto toga preporučuje se pisanje u bezličnoj formi, kao na primjer: smatra se, istraživanja pokazuju i slično. Shodno navedenome, ni vlastitim istraživanjima ne treba davati preveliko značenje, jer će recepcija od strane čitateljstva biti bolja ukoliko se koristi konstrukcija bezlične forme.

Također, u pisanju je potrebno izbjegavati korištenje poštapalica tipa opće je poznato, svako to zna, jasno je kao dan i tome slično. Kod pisanja brojeva, isto tako postoje jezička pravila. Svi brojevi od jedan do deset pišu se slovima, dok svi ostali numerički. Ukoliko se, međutim, u istoj rečenici pojavljuju obje vrste brojeva, onda se pribjegava pravilu da se sve piše numerički.

Naučni i stručni rad nije neovisan od stila pisanja. Stil je, po definiciji, izbor izražajnih sredstava u jeziku. Izgrađenost stila pisanja bitno utječe na recepciju čitalačke publike. Stil mora biti jasan, neusiljen, jednostavan, originalan, pun mašte, živosti i harmonije.

Među stilovima pisanja postoje ogromne razlike, koje uglavnom reflektiraju naučno područje. $U$ tome kontekstu razlikujemo književnoumjetnički, publicistički, administrativni, naučni, naučnopopularni stil, itd. Međutim, svaki od njih ima posebna svojstva po kojima se razlikuje od drugih. Kod naučnoistraživačkih radova prakticira se naučni stil u kojem se ističu logička obilježja onoga što se izlaže, intelektualni elementi jezika i naučni izrazi. Također, naučni stil insistira na jednostavnosti, jasnoći, kratkoći i logičnosti misli i ideja, kao i rezultata naučnoistraživačkog rada. S druge strane, naučni stil izbjegava intimnost, individualnost i osjećajnost, što su obilježja književnoumjetničkog stila. Stil koji ima elemente novinarskog i naučnog, te čija su glavna obilježja kratkoća, jasnoća, a nerijetko i polemička oštrina nazivamo publicističkim stilom.

Stil koji koristi kombinaciju naučnog, književnoumjetničkog i publicističkog u isto vrijeme naziva se naučnopopularni stil. Ovaj stil se koristi obično kada autor želi da se obrati ne samo specijaliziranoj naučnoj, već široj čitalačkoj publici, kako bi svoje pisano izlaganje učinio življim. U takvim slučajevima autor stručnu terminologiju podređuje opisima, književnim izrazima i slično. 
Govoreći uopćeno o pravilima dobroga pisanja sugeriraćemo samo neka:

a) Nikada ne upotrebljavaj veliku riječ ako ti je mala dovoljna;

b) Nikada ne upotrebljavaj dvije riječi ako je dovoljna jedna;

c) Izbjegavaj pasiv u svim slučajevima

d) Uvijek pustite da glagoli nose glavni teret u izražavanju misli.

Ovdje ćemo spomenuti bosanskohercegovačkoga stručnjaka u području metodologije, M. Šamića, koji navodi tri svojstva dobroga stila kod pisanja naučnog ili stručnog rada, a to su: jasnoća, jednostavnost $i$ konciznost.

Jasnoća, prema Šamiću, predstavlja sposobnost jezičkog izražavanja na način da kod čitalaca razvija iste ili slične misli i osjećaje kao i kod autora u vrijeme dok je pisao rad. Ovo svojstvo autor može postići isključivo ako je svjestan, dok piše rad, da ga piše za druge, odnosno da drugima želi prenijeti svoje misli i impresije o određenome pitanju, pojavi ili procesu, te shodno tome svoje misli izrazi na način da ga čitaoci bez poteškoća razumiju. U radovima koji nemaju dovoljan stepen jasnoće, kada su u pitanju iznošenje argumenata, suprotstavljanje protuargumenata i izvođenje zaključaka, postoji rizik da čitaoci neće biti u stanju raspoznati cilj i svrhu autorovog nastojanja. Čitaoce, također, često zbunjuje upotreba stavova koji su suvišni ili na pogrešnome mjestu.

Jednostavnost $i$ odmjerenost je drugo svojstvo koje navodi Šamić, a podrazumijeva da stil pisanja u naučnom radu ne smije biti pretenciozan, patetičan, strastven, emfatičan (neodmjereno napuhan), dijaboličan (pretjerano nakićen), panegiričan (hvalisav), skeptičan (sumnjičav) i hiperkritičan (koji pretjerano kritizira). U tom kontekstu, jednostavnost, prirodnost i odmjerenost su odlike dobrog naučnog stila, kojem ne fali ni dinamike ni duha.

Konciznost, kao treće svojstvo dobroga stila, podrazumijeva racionalnost u izražavanju, te konciznost izraza koja se postiže izbjegavanjem opisnog načina iskazivanja i tautologije. U osnovi, ono što ničemu ne služi, zapravo šteti.

Da bi navedena svojstva primijenili u svoj stil pisanja, temeljna pretpostavka je da pažljivo vršimo izbor riječi, vodimo računa o 
strukturi i bitnim osobinama rečenice te strukturi i osobinama paragrafa ili odjeljaka. Fokusiranje čitalačke pažnje na iznesene ideje, argumente i dokaze na način da ih percipiraju onako kako ih i autor razumije, u osnovi znači da je korišten primjeren stil pisanja.

\section{Zaključak}

Svaki naučni ili stručni rad podrazumijeva određeno planiranje, analizu i kontrolu urađenog, odnosno komponiranje rada zahtjeva njegovu organizaciju i logičku povezanost svih njegovih dijelova, od sažetka, uvoda, glavnog dijela do zaključka, odnosno popisa literature. Poteškoće i pogreške s kojima se autori susreću, u procesu stvaranja svojih radova, su raznorodne i uvjetovane različitim okolnostima, te smo se ovdje fokusirali samo na neke od njih, sugerirajući kako ih prevladati i kako zadovoljiti konvencionalne standarde i norme $\mathrm{u}$ postupku pisanja.

Relevantnost određenog naučnog i stručnog rada nije samo u njegovoj istinitosti, već postoji niz kriterija i metodoloških zahtjeva od strane izdavača koje treba zadovoljiti. Pri odabiru naučnih i stručnih radova, osnovni zahtjevi izdavača su aktuelnost i relevantnost istraživanog predmeta, uvažavanje standarda naučnih dokaza, suprotstavljanje argumenata $z a$ i protiv, te razumljivost samog rada. Uz poštivanje navedenih kriterija, autori prilikom pisanja svojih radova trebaju uvažavati i opće konvencionalne standarde koji su nezaobilazni okviri relevantnog naučnog i stručnog rada. U fokusu su, prije svega, objektivnost i preciznost u izlaganju naučne spoznaje, sistematičnost, provjerljivost svih dokaza koji se prezentiraju naučnoj publici i kompozicijska uvezanost svih dijelova rada. U kontekstu navedenih kriterija i standarda, uvažavanjem jezičkih normi i odabirom prihvatljivog stila pisanja, autor sa sigurnošću može očekivati da njegov pisani rad bude prihvaćen i pozitivno ocijenjen kako od strane izdavača i recenzenata tako i naučne javnosti, što je krajnji cilj svakog autora.

\section{Literatura:}

1. Kniewald, J., Metodika znanstvenog rada, Multigraf, Zagreb, 1993.

2. Krippendorf, K., Content Analysis - An Introduction to Its Methodology, Sage Publication, Beverly Hills, London, 1981. 
3. Kukić, S. - Demirović, M., Metodologija znanstvenoistraživačkog rada, Mostar Bihać, 2003.

4. Milardović, A., Metodologija politologije, Pan liber, Osijek - Zagreb - Split, 1998.

5. Miller, C. Delbert, Handbook of Research Desing and Social Measurement, David Mc Kay Company, New York, 1970.

6. Milovanović, M. Pisanje, uređivanje i štampanje, NIRO Tehnička knjiga, Beograd, 1979.

7. Šamić, M., Kako nastaje naučno djelo - uvođenje u metodologiju i tehniku naučnoistraživačkog rada, Sarajevo, 1980.

8. Weber, M., Metodologija društvenih nauka, Globus, Zagreb, 1986. 


\section{SOME METHODOLOGICAL ASSUMPTIONS FOR WRITING OF A SCIENTIFIC OR PROFESSIONAL PAPER WORK}

\section{SUMMARY}

This article points out the basic methodological assumptions related to writing a scientific or professional paper work. Those can be very useful to all who are dealing with research and want to publish their research results. The Author particularly refers to the importance of the research subjects; relevance of the research questions, acceptance and appliance of the standards related to the scientific proves, as well as argumentation and comprehensibility of the scientific paper work. Each Article with its content should influence the research problem solving, respectively if the professional paper is in question, new dimension of appliance or explanations of the issues that are being elaborated should be given. Moreover, one other type of the Article should send out the ideas and opinions that will be valuable for the readers. Writing the scientific and professional papers imply understanding the materials that are written about, use of the suitable methods, acceptance and appliance of the methodological standards and respecting lingual and stylistic regulations.

Key words: scientific article, professional article, methodology, scientific research work, composition of the scientific paper work, scientific language, writing style. 


$$
\text { الأستاذ المساعد د. نوزت ويلاجيتش }
$$

\section{بعض الافتراضات المنهجية لكتابة المقالة العلمية أو المهنية}

\section{خلاصة البحث}

هذا البحث يلفت الانتباه إلى بعض الافتراضات المنهجية الأساسية لكتابة البحوث

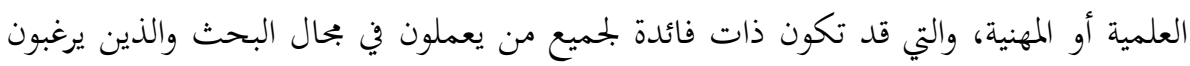

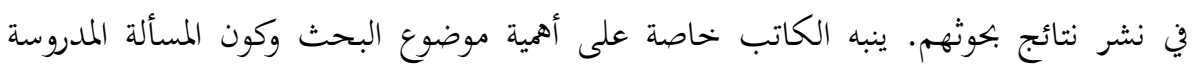

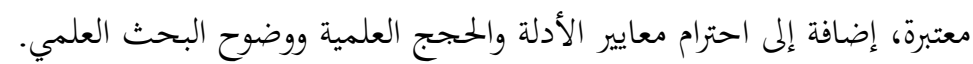

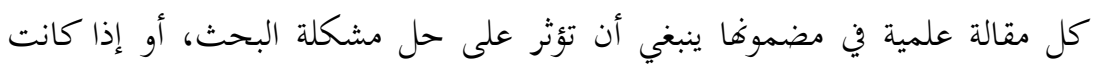

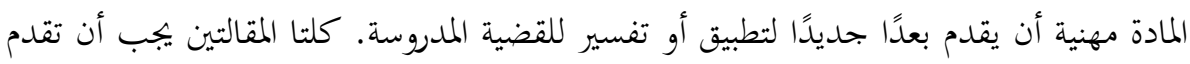

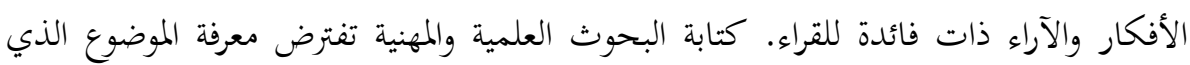

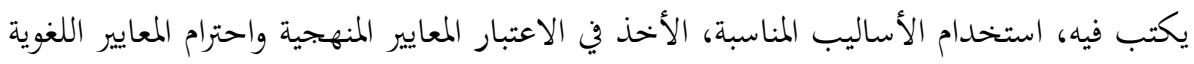
والأسلوبية.

الكلمات الئيسة: المقالة العلمية، المقالة المهنية، المنهجية، البحث العلمي، تكوين العمل العلمي، اللغة العلمية، أسلوب الكتابة. 